\title{
Implementasi Klausul Transfer of Undertaking (Protection of Employment) Bagi Outsourcing Employee Perusahaan yang Jatuh Pailit
}

\author{
Wira Maulana Aulia Akbar \\ wiramaulana8@gmail.com \\ Universitas Airlangga
}

\begin{abstract}
In outsourcing business activities, there are two forms of agreements that can be made to create employment relationships, namely a certain time work agreement (PKWT) and an non-certain time work agreement (PKWTT). In the decision of the Constitutional Court also offers solutions for worker protection for outsourced workers if the employment relationship of workers / laborers with service provider companies has been exhausted. The first is the worker / laborer can enter into an employment agreement with an indefinite time work agreement (PKWTT). The second is that workers / laborers are bound by a specific time work agreement (PKWT). With this agreement also applies the Transfer of Undertaking Protection of Employment (TUPE) clause where workers get protection in the form of a transfer of work from the old Service Provider Company to the new Service Provider Company. Due to the bankruptcy of a bankrupt company, workers / laborers when working for a bankrupt company, have the right to resign from a work relationship, and also with the curator can also terminate employment relations with workers from companies that have been declared bankrupt. Then the directors and commissioners of a bankrupt company which is declared bankrupt are not allowed to become directors and commissioners of other companies.

Keywords: Outsourcing Construction; TUPE; As a Result of PPJP Bankruptcy.
\end{abstract}

\begin{abstract}
Abstrak
Dalam kegiatan usaha bisnis alih daya (outsourcing), Ada dua bentuk perjanjian yang dapat dilakukan untuk menimbulkan hubungan kerja, yaitu perjanjian kerja waktu tertentu (PKWT) dan perjanjian kerja waktu tidak tertentu (PKWTT). Pada putusan Mahkamah Kosntitusi juga menawarkan solusi perlindungan pekerja/buruh outsourcing apabila hubungan kerja pekerja/buruh dengan perusahaan penyedia jasa telah habis. Yang pertama pekerja/buruh dapat melakukan perjanjian kerja dengan perjanjian kerja waktu tidak tertentu (PKWTT). Yang kedua yaitu pekerja/buruh diikat dengan perjanjian kerja waktu tertentu (PKWT). Dengan perjanjian ini juga diterapkan klausul Transfer of Undertaking Protection of Employment (TUPE) dimana pekerja mendapat perlindungan berupa pengalihan kerja dari Perusahaan Penyedia jasa yang lama ke Perusahaan Penyedia Jasa yang baru. Akibat hukum pailitnya sebuah perusahaan yang pailit, maka pekerja/ buruh ketika bekerja untuk perusahaan yang pailit,memiliki hak untuk mengundurkan diri dari hubungan kerja, dan begitupula dengan kurator juga bisa memutus hubungan kerja kepada pekerja dari perusahaan yang telah dinyatakan pailit. Kemudian direktur dan komisaris dari suatu perseroan terbatas yang dinyatakan pailit tidak diperbolehkan menjadi direksi dan komisaris dari perusahaan lainnya.
\end{abstract}

Kata Kunci: Konstruksi Outsourcing; TUPE; Akibat Pailitnya PPJP. 


\section{Pendahuluan}

Penggunaan sistem alih daya (outsourcing) yang diserahkan kepada perusahaan penedia jasa pekerja oleh perusahaan pemberi kerja diharapkan bahwa perusahaan pemberi kerja lebih untuk mengutamakan terhadap manajemen produksi/jasa perusahaan tersebut. Namun sistem yang diharapkan dapat bertujuan baik tersebut masih menimbulkan permasalahan yang dilakukan, seperti ketidaksesuaian hak dan kewajiban dalam perjanjian kerja yang dilakukan oleh perusahaan penyedia jasa pekerja, sehingga menyebabkan kedudukan pekerja outsourcing berada pada posisi yang mengkhawatirkan untuk bisa mendapatkan hak sebagai pekerja/buruh sebagaimana ketentuan yang diatur menurut undangundang, kemudian juga pekerja/buruh outsourcing semakin menjadi sulit menghindari ketikausia pekerja bertambah dan berkurangnya kemampuan yang dimiliki untuk mendapatkan pekerjaan yang lain yang akhirnya menjadikan daya tawar kerja rendah.

Kepentingan tenaga kerja atas hak-hak pekerja/buruh yang dimaksud dalam penulisan ini yaitu ketika melihat hak serta kedudukan pekerja dengan kondisi pailitnya suatu perusahaan. Secara pelaksanaan operasional perusahaan, suatu kegiatan dari perusahaan belum tentu menunjukkan perkembangan yang baik-baik saja atau stabil serta dapat meeningkatan laba (profit) yang banyak bagi perusahaan. Ada kalanya resiko yang mungkin terjadi. Beberapa resiko yang mungkin saja dapat diterima oleh perusahaan, baik resiko dari investasi perusahaan serta dimungkinkan resiko dari pembiayaan maupun resiko operasional. Dimana hal tersebut bisa saja mengganggu perkembangan dari keuangan perusahaan dan bisa menyebabkan berakhir pailitnya perusahaan tersebut. Pada dasarnya pailitnya suatu perusahaan dapat terjadi ketika perusahaan tidak mampu untuk menjaga kestabilan pelunasan hutang secara periodik sesuai yang diperjanjikan dan justru hal tersebut memyebabkan semakin menumpuk hutang-hutang tersebut terhadap para kreditornya.

Perlindungan hukum bagi pekerja/buruh alih daya sepenuhnya menjadi tanggung jawab dari perusahaan penyediajasa pekerja (PPJP). Hal tersebut 
dikarenakan perjanjian kerja terjadi antara pekerja/buruh dengan Perusahaan Penyedia Jasa Pekerja (PPJP), sehingga bila dikemudian hari perusahaan penyedia jasa pekerja mengalami kondisi pailit dengan adanya putusan pailit dari pengadilan dan menyebabkan ketidakmampuan untuk mengelola pekerja/buruh yang dipekerjakannya, sehingga pekerja/buruh outsourcing tersebut berhak untuk diberikan perlindungan hukum untuk mendapatkan seluruh haknya sebagai pekerja dan apa yang seharusnya didapatkan seperti yang dijelaskan dalam Pasal 165 Undang-Undang Nomor 13 Tahun 2003, dan juga kedudukan pekerja dalam pembayaran upahnya dibayarkan dahulu menurut UndangUndang sesuai ketentuan Pasal 95 ayat (4) Undang-Undang Nomor 13 Tahun 2003 Tentang Ketenagakerjaan, yang menyatakan ketika sebuah perusahaan dalam kondisi telah dinyatakan pailit atau likuidasi menurut ketentuan perundangundangan, maka upah serta hak lainnya untuk pekerja/buruh dianggap sebagai utang yang pembayarannya sepatutnya didahulukan.

Beberapa faktor yang menjadikan perusahaan dinyatakan dalam kondisi pailit terjadi karena kurang efisiensi dalam hal manajemen perusahaaan tersebut seperti pengeluaran biaya perusahaan untuk pembiayaan tertentu yang cukup besar serta ketidakseimbangan pemasukan yang didapatkan perusahaan, sehingga hal ini yang menyebabkan perusahaan outsourcing akhirnya harus memutus kontrak kerja dengan para pekerja/buruh secara sepihak walaupun pekerjaan yang dioutsourcingkan diperusahaan pemberi kerja masih ada dan sebenarnya perjanjian hubungan mitra kerja sama dengan Perusahaan Penyedia Jasa Pekerja (PPJP) masih belum berakhir disebabkan perusahaan telah dinyatakan pailit oleh Pengadilan. Efek dari pailitnya perusahaan penyedia jasa pekerja dapat mengakibatkan ketidakstabilan manajemen perusahaan dan membuat kurangnya kepercayaan dari pihak perusahaan pemberi kerja, dimana hal ini dapat mengakibatkan terhadap pekerja/buruh yang ditempatkan harus keluar dari perusahaan pengguna outsourcing/pemberi kerja walaupun sebenarnya perjanjian kerja dengan PPJP belum berakhir sesuai kontrak yang telah diperjanjikan dalam perjanjian kerja. 
Permasalahan perburuhan terkait dengan perusahaan penyedia jasa yang mengalami pailit yaitu terletak pada perbedaan kedudukan hukum dan hak ekonomi yang terkait pembayaran dalam kepailitan antara kreditor separatis dan buruh. Bagi kreditor separatis, pembayaran dalam kepailitan dijamin dengan pelunasannya berupa hipotek, agunan, fidusia, gadai dan hak tanggungan. Bagi buruh, selaku kreditor preferen, maka kedudukannya berada di bawah kreditor separatis menurut jenis-jenis kreditor dalam kepailitan, sehingga harta milik debitor yang menjadi agunan akan dieksekusi oleh kreditor separatis. Dengan demikian besar kemungkinan pekerja atau buruh hanya akan mendapatkan sedikit saja hakhaknya atau bahkan dimungkinkan tidak mendapat apapun dari hakya.

Kedudukan para pekerja/buruh outsourcing ini menjadi kewajiban dari Perusahaan Penyedia Jasa Pekerja (PPJP) untuk tetap tanggung jawab memberikan perlindungan seluruh hak pekerja/buruh outsourcing yang belum dibayarkan atau mungkin pekerja diberhentikan sebelum masa kontraknya berakhir menurut perjanjian kerja dikarenakan perusahaan mengalami keadaan pailit. Berdasarkan Peraturan Perundang-undangan terkait seperti Undang-Undang Ketenagakerjaan, Undang-Undang Kepailitan dan Penundaan Kewajiban Pembayaran Utang, Putusan Mahkamah Konstitusi No. 27/PUU-IX/2011 serta Peraturan Menteri Tenaga kerja dan Transmigrasi No.19 Tahun 2012 tentangSyarat-SyaratPenyerahan Pekerjaan Kepada Perusahaan Lain, maka pekerja/buruh alih daya diharuskan tetap mendapatkan perlindungan hukum dan penyelesaian terhadap seluruh haknya dari perusahaan penyedia jasa pekerja (PPJP) yang telah dinyatakan pailit oleh Pengadilan. ${ }^{1}$

Mahkamah Konstitusi menjelaskan dua bentuk perjanjian kerja yang dapat digunakan untuk melindungi hak-hak pekerja/buruh. Pertama, dimana dengan mensyaratkan agar perjanjian kerja antara pekerja/buruh dengan perusahaan yang melaksanakan pekerjaan outsourcing ini tidaklah berbentuk PKWT, melainkan berbentuk "perjanjian kerja waktu tidak tertentu" atau PKWTT. Kedua, dapat pula

\footnotetext{
${ }^{1}$ Andre Azka Hanifan, 'Perlindungan Hukum Pekerja Alih Daya Di Perusahaan Penyedia Jasa Pekerja Pailit’ (2014) XIX Perspektif.[85].
} 
dengan PKWT dimana menerapkan prinsip pengalihan tindakan perlindungan bagi pekerja/buruh yaitu Transfer of Undertaking Protection of Employment atau TUPE yang bekerja pada perusahaan yang melaksanakan pekerjaan outsourcing. Perbedaan Model perjanjian ini yaitu jika perjanjian kerja waktu tidak tertentu ini memberikan perlindungan hak-hak buruh secara pasti karena statusnya adalah pegawai tetap dan kelanjutan pekerjaannya dijamin oleh Undang-Undang. Sedangkan melalui model perjanjian kerja waktu tertentu atau PKWT perlu menggunakan prinsip Transfer of Undertaking Protection of Employment (TUPE) atau prinsip pengalihan tindakan perlindungan untuk pekerja/buruh.

Hakekatnya Mahkamah Konstitusi ingin melindungi hak-hak para pekerja yang dimana perusahaan penyedia jasa pekerja tidak bekerja sama dengan perusahaan pemberi kerja meskipun pekerjaan itu masih tetap ada, sehingga seluruh hak pekerja/buruh akan beralih dari perusahaan yang lama ke perusahaan yang baru akan tetap dilindungi. Prinsip ini dijelaskan dalam butir (3.18) pertimbangan hukum putusan Mahkamah Konstitusi Perkara Nomor 27/ PUU-IX/2011 (Putusan MK), yang pada intinya dengan menerapkan prinsip perlindungan TUPE, ketika perusahaan pemberi kerja tidak lagi memberikan pekerjaan borongan atau penyedia jasa pekerja/ buruh kepada suatu perusahaan penyedia jasa atau outsourcing yang lama, maka akan memberikan pekerjaan tersebut kepada perusahaan penyedia jasa outsourcing yang baru, selama pekerjaan yang diperintahkan untuk dipekerjakan tersebut masih ada dan berlanjut, perusahaan penyedia jasa baru tersebut harus tetap melanjutkan kontrak kerja yang telah ada sebelumnya, tanpa mengubah ketentuan apapun yang ada dalam kontrak, tanpa persetujuan pihak-pihak yang berkepentingan, kecuali perubahan itu hanya untuk meningkatkan keuntungan bagi pekerja/ buruh karena bertambahnya pengalaman dan masa kerjanya.

Dalam kaitannya dengan hubungan hukum ketenagakerjaan, tentunya tidak lepas dari apa yang dinamakan dengan perjanjian kerja. Bentuk dari perjanjian kerja tersebut bisa lisan maupun tertulis, tetapi pada outsourcing pada umumnya berbentuk tertulis sebab telah diatur dalam Undang-undang No. 13 Tahun 2003. 
Perjanjian kerja mengatur mengenai hak dan kewajiban para pihak, selain itu juga harus sesuai dengan hukum perjanjian. Dalam perjanjian adanya beberapa asas yaitu konsensus serta asas kebebasan berkontrak sebagaimana terdapat pada pasal 1338 Burgerlijk Wetboek, selanjutnya disingkat BW, namun adanya batasanbatasan tertentu seperti tertuang dalam pasal $1320 \mathrm{BW}$.

Asas kebebasan berkontrak dalam hukum perjanjian Indonesia menurut Sutan Remi Sjahdeini meliputi ruang lingkup sebagai berikut: ${ }^{2}$

a. Kebebasan untuk membuat atau tidak membuat perjanjian;

b. Kebebasan untuk memilih pihak dengan siapa ia ingin membuat perjanjian;

c. Kebebasan untuk menentukan atau memilih kausa daru perjanjian yang akan dibuatnya;

d. Kebebasan untuk menentukan bentuk suatu perjanjian.

Perjanjian kerja juga diatur menurut pasal 52 Undang-undang Nomor 13 Tahun 2003 tentang Ketenagakerjaan yang dibuat atas dasar:

a. Kesepakatan yang dilakukan antara kedua belah pihak;

b. Kecakapan untuk dapat melakukan perbuatan hukum;

c. Adanya pekerjaan yang telah diperjanjikan antara para pihak;

d. Pekerjaan yang diperjanjikan tidak bertentangan dengan ketertiban umum, kesusilaan dan peraturan perundang-undangan yang berlaku.

Perjanjian kerja dibagi menjadi 2 (dua) yakni:

a. Perjanjian kerja waktu tertentu.

b. Perjanjian kerja waktu tidak tertentu.

Perjanjian kerja waktu tertentu ini dibuat untuk hubungan kerja yang dibatasi oleh jangka waktu berlakunya perjanjian atau selesainya pekerjaan tersebut. Untuk perjanjian kerja waktu tidak tertentu dibuat untuk hubungan kerja yang tidak dibatasi oleh jangka waktu berlakunya perjanjian atau selesainya pekerjaan tertentu. ${ }^{3}$

\section{Konstruksi Hukum Perjanjian Outsourcing}

Dalam kegiatan usaha bisnis alih daya (outsourcing), para pihak akan melakukan perjanjian kerja terlebih dahulu. Perjanjian ini dilakukan oleh pekerja/

\footnotetext{
${ }^{2}$ Agus Yudha Hernoko, Hukum Perjanjian Asas Proporsionalitas Dalam Kontrak Komersial (Kencana Prenada Media Group 2010).[110-111].

3 Lanny Ramli, Hukum Ketenagakerjaan (Airlangga University Press 2008).[26].
} 
buruh dengan pengusaha penyedia jasa pekerja yang memuat syarat kerja, hak dan kewajiban. Perjanjian kerja ini dapat dibuat secara tertulis maupun lisan. Sehingga ketika para pihak melakukan perjanjian kerja, maka akan menimbulkan hubungan kerja yang terjadi antar para pihak.

Menurut ketentuan pasal 52 ayat (1) Undang-Undang Nomor 13 Tahun 2003 pada dasarnya perjanjian kerja dibuat dengan adanya kesepakatan para pihak, kemudian kecakapan untuk melakukan perbuatan hukum, adaya pekerjaan yang diperjanjikan serta pekerjaan tersebut tidak melanggar ketertiban umum, kesusilaan dan juga pertauran perundang-undangan yang berlaku. Menurut Aloysius Uwiyono perjanjian kerja pada prinsipnya adalah perjanjian, oleh sebab itu sepanjang mengenai ketentuan yang sifatnya umum. Hubungan keterkaitan antara perjanjian kerja dengan perjanjian pada umumnya, dapat dilihat di ketentuan yang mengatur perjanjian kerja tersebut sebagaimana bab 7 (lama) atau bab 7a dari buku ketiga KUH Perdata. ${ }^{4}$

Dalam suatu hubungan kerja perlu diketahui pula dasar terjadinya hubungan tersebut. Menurut pasal 1 angka 15 UU No. 13 Tahun 2003 menjelaskan hubungan kerja adalah hubungan antara pengusaha dengan pekerja/buruh berdasarkan perjanjian kerja, yang mempunyai unsur pekerjaan, upah dan perintah. Undang-Undang No. 13 Tahun 2003 membedakan definisi dari Tenaga Kerja dan Pekerja/ buruh. Menurut pasal 1 angka 2 UU No. 13 Tahun 2003 dimana tenaga kerja merupakan setiap orang yang dapat melakukan pekerjaan agar dapat menghasilkan barang dan/atau jasa baik untuk memenuhi kebutuhan dirinya sendiri maupun untuk masyarakat. Sedangkan menurut ketentuan Pasal 1 angka 3 UU No. 13 Tahun 2003 terkait pekerja/buruh yaitu setiap orang yang bekerja dengan menerima upah (gaji) atau imbalan dalam bentuk lain.

Hubungan kerja adalah dimana adanya hubungan antara pengusaha dengan buruh berdasarkan perjanjian kerja, yang mempunyai unsur pekerjaan, upah, dan perintah. Ada dua bentuk perjanjian yang dapat dilakukan untuk 
menimbulkan hubungan kerja, yaitu perjanjian kerja waktu tertentu (PKWT) dan perjanjian kerja waktu tidak tertentu (PKWTT). Perjanjian kerja yang dibuat untuk waktu tertentu biasanya disebut dengan perjanjian kerja kontrak atau perjanjian kerja tidak tetap. Hal tersebut dikarenakan status pekerjaanya adalah pekerja tidak tetap atau pekerja kontrak. Sedangkan untuk perjanjian kerja yang dibuat untuk waktu tidak tertentu biasanya disebut dengan perjanjian kerja tetap dan status pekerjaannya juga menjadi pekerja tetap. ${ }^{5}$ Undang-undang Ketenagakerjan mengenai pelaksanaan sistem alih daya atau outsourcing sendiri ada 2 (dua) model, yaitu pekerjaan dapat dilakukan dengan sistem pemborongan atau bisa juga melakukan penyediaan jasa bagi buruh sesuai ketentuan dalam pasal 64 Undang-Undang Ketenagakerjaan. ${ }^{6}$

Terkait dengan pelaksanaan sistetm pemborongan kerja diatur dalam pasal 65 ayat (2) dalam UU Ketenagakerjaan, dimana adanya syarat dalam melakukan perjanjian ini yaitu perjanjian dilakukan secara tertulis dan adanya beberapa persyaratan pekerjaan yang dapat diborongkan yaitu:

1. Pekerjaannya dilakukan secara terpisah dari pekerjaan atau kegiatan utama dari perusahaan tersebut;

2. Pekerjaannya dilakukan dengan adanya perintah langsung maupun tidak langsung dari pemberi kerja;

3. Merupakan pekerjaan yang sifatnya penunjang perusahaan secara keseluruhan;

4. Tidak menjadi hambatan dalam proses produksi secara langsung.

Outsourcing (Alih daya) sebagai suatu usaha bisnis penyediaan tenaga kerja terlebih dahulu perlu memisahkan antara pekerjaan utama (Core Business) dan pekerjaan penunjang (non core business). Yang dinamakan pekerjaan utama (Core Business) yaitu pekerjaan yang sifatnya pokok (utama) atau pekerjaannya terkait dengan kegiatan produksi dari perusahaan tersebut. Sedangkan yang dimaksud kegiatan jasa penunjang atau kegiatan yang tidak berhubungan langsung dengan proses produksi adalah kegiatan yang berhubungan di luar usaha pokok suatu

\footnotetext{
${ }^{5}$ Lalu Husni, Pengantar Hukum Ketenagakerjaan Indonesia (Rajawali Press 2012).[68].

6 Marwati Riza, Perlindungan Pekerja Migran Indonesia di Luar Negeri (AS Publishing 2009). [122].
} 
perusahaan. ${ }^{7}$ Adapun kegiatan penunjang tersebut antara lain seperti usaha pelayanan kebersihan, usaha penyediaan makanan bagi pekerja/buruh, usaha tenaga pengaman (satuan pengamanan), usaha jasa penunjang di pertambangan dan perminyakan, serta usaha penyediaan angkutan pekerja/buruh.

Hubungan kerja yang dilakukan antara pekerja/buruh outsourcing dengan perusahaan penyedia jasa pekerja (PPJP) terjadi ketika pekerja/buruh telah menandatangani perjanjian kerja sebagai dasar timbulnya hubungan ketenagakerjaan dengan perusahaan penyedia jasa pekerja. Perjanjian kerja antara karyawan dengan perusahaan outsourcing dapat berupa Perjanjian Kerja Waktu Tertentu (PKWT) maupun Perjanjian Kerja Waktu Tidak Tertentu (PKWTT) sebagaimana diatur dalam pasal 56 sampai 60 Undang-Undang Ketenagakerjaan. Oleh sebab itu, dalam sistem outsourcing ini pemenuhan hak bagi para pekerja seperti perlindungan upah dan kesejahteraan, syaratsyarat kerja serta perselisihan yang timbul tetap merupakan tanggung jawab perusahaan penyedia jasa pekerja. ${ }^{8}$

Berdasarkan ketentuan pasal50Undang-Undang No.13Tahun2003, hubungan kerja terjadi dikarenakan adanya perjanjian kerja antara pengusaha dan pekerja/ buruh. Dari adanya ketentuan tersebut maka dapat dilihat bahwa hubungan kerja yang terjadi dilakukan oleh dua subyek hukum yaitu pengusaha dan juga pekerja/ buruh. Adapun kewajiban hukum yang ada dalam perjanjian kerja antara pemberi kerja terhadap perusahaan penyedia outsourcing (vendor) adalah:

1. Memberikan pekerjaan kepada perusahaan penerima pekerjaan atau Perusahaan Penyedia Jasa Pekerja (PPJP);

2. Memuat ketentuan yang menjamin terpenuhinya hak dan kewajiban perjanjian kerja;

3. Mengadakan perjanjian secara tertulis dalam bentuk MoU;

4. Dalam hal penempatan pekerja/buruh maka perusahaan pemberi pekerjaan akan membayar sejumlah dana (fee) pada perusahaan penyedia jasa pekerja/ buruh.

${ }^{7}$ Christopher Ganadhi, ‘Tanggung Jawab PPJP Sebagai Penerima Pekerja Outsourcing Dari PPJP Sebelumnya Apabila Terjadi PHK' (2018) 1 Yuridika [17].

8 Adrian Sutedi, Hukum Perburuhan (Sinar Grafika 2009).[49]. 
Dengan demikian maka hak bagi perusahaan outsourcing selaku penerima pekerjaan yaitu:

1. Menerima pekerjaan penunjang yang dioutsourcingkan dari perusahaan pemberi pekerjaan;

2. Menerima pekerjaan dari perusahaan pemberi pekerjaan dalam bentuk hubungan kerja sama.

Marwati Riza juga menyatakan terkait persyaratan yang perlu dilaksanakan untuk pelaksanaan outsourcing mengenai hubungan kerja yaitu antara lain: ${ }^{9}$

1. Terdapat adanya hubungan kerja antara pekerja dengan perusahaan penyedia jasa tenaga kerja;

2. Perjanjian kerja dapat dibuat secara tertulis baik berupa Perjanjian Kerja Waktu Tertentu (PKWT) maupun Perjanjian Kerja Waktu Tidak Tertentu (PKWTT) yang dilakukan dengan ditantangani oleh para pihak;

3. Perusahaan Penyedia Jasa Pekerja (PPJP) mempunyai kewajiban dalam hal memberikan perlindungan terkait gaji untuk kesejahterahan pekerja, terkait syarat pelaksanaan kerja serta perselisihan yang dimungkinkan dapat terjadi.

\section{Klausula TUPE Dalam Perjanjian Outsourcing}

Model pelaksanaan outsourcing (alih daya) yang diatur dalam UndangUndang Nomor 13 Tahun 2003 tentang Ketenagakerjaan ini masih adanya permasalahan karena para buruh/pekerja outsourcing merasa dirugikan karena kurangnya perlindungan dan pengawasan dari pemerintah. Pada tahun 2011, Didik Supriadi mewakili Aliansi Petugas Pembaca Meter Listrik Indonesia (AP2MLI) mengajukan judicial riview terhadap ketentuan pasal 59, pasal 64, pasal 65 dan pasal 66 Undang-Undang Ketenagakerjaan. Mahkamah Konstitusi sebagai lembaga yang berwenang untuk melakukan judicial review di dalam amar putusannya mengabulkan permohonan Didik Supriadi untuk sebagian dan menolak permohonan pada permohonan tertentu.

9 Marwati Riza, Op.Cit.[134]. 
Dalam pertimbangan putusan menjelaskan bahwa Mahkamah Konstitusi pada dasarnya tidak melarang perjanjian kerja waktu tertentu (PKWT) asalkan sesuai dengan pasal 59 UU Ketenagakerjaan. Perjanjian ini hanya sebatas pada pekerjaan yang hanya sementara, kegiatan kerjanya tidak lama atau setidaknya hanya 3 (tiga) tahun, kegiatan kerja hanya musiman serta kegiatan kerjanya dapat terkait dengan pelaksanaan produk baru yang sifatnya tidak tetap.

Dalam pelaksanaan kegiatan alihdaya atau outsourcing masih banyak jenis pekerjaan yang dapat dioutsourcingkan yang diharapkan agar dapat mengutamakan pelaksanaan kegiatan kerja perusahaan sehingga pekerjaan lain yang bukan menjadi prioritas akan diserahkan untuk dipekerjakan kepada Perusahaan penyedia jasa pekerja (PPJP). Untuk menjaga kepentingan atas hak dari pekerja/buruh, maka dalam Pasal 65 ayat (4) UU Ketenagakerjaan menyatakan pemberian perlindungan serta syarat pelaksanaan kerja untuk pekerja/buruh pada perusahaan penyedia jasa setidaknnya juga tidak berbeda dengan penerapan perlindungan pekerja serta persyaratan dalam bekerja pada perusahaan pengguna outsourcing (pemberi kerja) atau setidaknya juga sama dengan peraturan perundang-undangan terkait.

Pada putusan Mahkamah Kosntitusi juga menawarkan solusi perlindungan pekerja/buruh outsourcing apabila hubungan kerja pekerja/buruh dengan perusahaan penyedia jasa telah habis. Yang pertama pekerja/buruh dapat melakukan perjanjian kerja dengan perjanjian kerja waktu tidak tertentu (PKWTT). Model perjanjian ini memberi perlindungan hak-hak buruh secara pasti karena statusnya adalah pegawai tetap dan kelanjutan pekerjaannya dijamin oleh undang-undang dan apabila bila terjadi pemutusan hubungan kerja perlu melewati tahap-tahap tertentu. Yang kedua yaitu pekerja/buruh diikat dengan perjanjian kerja waktu tertentu (PKWT). Dengan perjanjian ini juga diterapkan klausul Transfer of Undertaking Protection of Employment (TUPE) dimana ketika perusahaan pemberi kerja tidak lagi memberikan pekerjaan borongan atau penyediaan jasa pekerja/buruh pada perusahaan outsourcing yang lama dan memerikan pekerjaan tersebut kepada perusahaan outsourcing yang baru. 
Sehingga perusahaan penyedia jasa yang baru melanjutkan kontrak kerja yang ada sebelumnya, tanpa mengubah isi ketentuan perjanjian, kecuali perubahan tersebut menguntungkan bagi pekerja karena bertambahnya pengalaman dan masa kerja. Dengan model perjanjian tersebut, Mahkamah Konstitus menjawab kegelisahan para pekerja/buruh outsourcing terkait kelanjutan masa kerja mereka bila masa kerja mereka dengan perusahaan telah habis dan terjadi pengalihan dari Perusahaan Penyedia jasa yang lama ke Perusahaan Penyedia Jasa yang baru. Jika sebelumnya pekerja/buruh perlu untuk membuat perjanjian baru untuk dapat bekerja pada Perusahaan Penyedia Jasa Pekerja (PPJP) yang baru, namun dengan prinsip pengalihan tindakan perlindungan bagi pekerja/buruh (TUPE), maka disini Mahkamah Konstitusi melindungi hak-hak pekerja/buruh karena apabila perusahaan pengguna outsourcing (pemberi kerja) sudah tidak memberikan pekerjaan kepada Perusahaan Penyedia Jasa Pekerja (PPJP) meskipun sebenarnya pekerjaan tersebut masih dipekerjakan, maka ketika ada PPJP baru yang bekerja sama dengan perusahaan pengguna outsourcing (pemberi kerja) tersebut wajib menjalankan kontrak kerja dari PPJP sebelumnya dengan pekerja/buruh, dengan tidak perlu merubah isi perjanjian kerja tersebut, kecuali perubahan tersebut sejatinya dapat meningkat keuntungan bagi pekerja/buruh karena bertambahnya masa kerja dan pengalamannya. Model pengalihan tindakan perlindungan (TUPE) ini setidaknya dapat memberi angin segar bagi pekerja/buruh dalam memberikan kepastian status kerja mereka dan sekaligus masa kerjanya tetap diakui dan tetap dihitung yang menyebabkan pekerja/buruh tersebut masih bisa menikmati hak yang sepatutnya diterima.

Dalam putusannya Mahkamah Konstitusi juga menegaskan bahwa PPJP didirikan dalam bentuk badan hukum yang terdaftar. Sebab hal ini dimaksudkan agar supaya adanya perlindungan bagi pekerja/buruh outsourcing mengenai kelangsungan pekerjaannya dan juga bagi Perusahaan Penyedia Jasa sendiri dengan status badan hukum yang sah maka kelangsungan usaha mereka tetap terjamin karena perusahaan tersebut telah memenuhi ketentuan yang diatur dalam Undang-Undang Ketenagakerjaan dan putusan Mahkamah Konstitusi 
karena untuk melakukan usaha outsourcing perusahaan perlu berbentuk badan hukum.

Menanggapi putusan Mahkamah Konstitusi No. 27/PUU-IX/2011, Keementerian Tenaga Kerja dan Transmigrasi sempat membuat Surat Edaran dengan Nomor B.31/PHIJSK/I/2012 yang pada intinya menjelaskan bahwa jika di perjanjian kerja antara perusahaan penerima atau perusahaan penyedia jasa pekerja/buruh dengan pekerja/buruhnya tidak adanya ketentuant syarat adanya pengalihan perlindungan hak-hak untuk pekerja/buruh yang obyek pekerjaannya tetap ada (sama), maka perjanjian kerja tersebut harus didasarkan pada perjanjian kerja waktu tidak tertentu (PKWTT). Namun jika di perjanjian kerja antara perusahaan pemberi kerja atau perusahaan penyedia jasa pekerja/buruh dengan pekerja/buruhnya ternyata sudah memuat ketentuan syarat mengenai pengalihan perlindungan hak-hak bagi pekerja/buruh yang obyek pekerjaan masih ada dan sama, maka hubungan hukum dapat didasarkan pada perjanjian kerja waktu tertentu (PKWT). Walaupun keberadaan perjanjian kerja yang telah disepakati oleh para pihak sebelum diterbitkannya putusan Mahkamah Konstitus, maka PKWT yang sedang berlangsung pada perusahaan pemberi kerja atau perusahaan penyedia jasa dengan pekerja/buruh outsourcing masih tetap berlaku hingga berakhirnya jangka waktu yang telah diperjanjikan.

\section{Akibat Hukum Kepailitan PPJP}

Kegagalan perusahaan bukanlah cacat bagi seorang pengusaha akan tetapi merupakan salah satu dimensi dari risiko usaha. Kebangkrutan merupakan adanya kondisi kesulitan keuangan yang sangat parah sehingga perusahaan tidak mampu lagi untuk menjalankan operasi perusahaan dengan baik. Sedangkan kesulitan keuangan (financial distress) adalah kesulitan keuangan atau likuiditas yang dimungkinkan dapat sebagai awal dari terjadinya kebangkrutan.

Ketidakmampuan tersebut juga harus disertai dengan suatu tindakan secara suka rela oleh Debitur sendiri, maupun dapat juga atas permintaan kreditur. Permohonan pailit sebagaimana yang dimaksud dalam Undang-Undang Kepailitan 
mengenai syarat pailit diatur dalam pasal 2 ayat (1), yang pada ininya menjelaskan bahwa debitor mempunyai dua atau lebih kreditor dan tidak membayar lunas sedikitnya satu utang yang telah jatuh waktu dan utang tersebut dapat ditagih, dinyatakan pailit dengan putusan Pengadilan, baik atas permohonannya sendiri maupun dapat juga atas permohonan satu atau lebih kreditornya. Sehingga untuk dapat dimohonkan pailit harus memenuhi syarat menurut ketentuan pasal 2 ayat (1) Undang-Undang No. 37 Tahun 2004.

Hak-hak debitor untuk melakukan semua tindakan hukum berkenaan dengan adanya kekayaan sebelum pernyataan pailit harus tetap dihormati. Dalam hal ini harus memperhatikan hak-hak kontraktual serta kewajiban debitor menurut ketentuan peraturan perundang-undangan. ${ }^{10}$

Munculnya putusan pailitolehPengadilan Niaga menimbulkankonsekuensi hukum bagi debitor maupun juga bagi kreditor. Zainal Asikin berpendapat bahwa akibat hukum dari adanya putusan pailit, maka konsekuensi yang paling utama yaitu dimana debitor akan kehilangan hak untuk melakukan pengurusan dari harta bendanya sendiri. Sehingga pengurusan dan pemberesan benda milik debitor tersebut akan beralih kepada kurator/balai harta peninggalan. ${ }^{11}$ Kehilangan hak penguasaan atas harta bendanya terhitung ketika sejak tanggal putusan kepailitan oleh debitor.Ketentuan pasal 25 Undang-Undang 37 Tahun 2004 tentang Kepailitan yang menyatakan ketika Debitor tidak diperkenankan untuk melakukan semua perikatan pasca adanya putusan pailit dimana pembayarannya dengan harta miliknya, namun dikecualikan jika perikatan tersebut oleh debitor bisa mendatangkan keuntungan bagi debitor itu sendiri. Akibat hukum lainnya juga datang dari pendapat Richard Burton Simatupang. ${ }^{12}$ Dimana hal lain yang perlu diperhatikan ketika adanya putusan pailit menurut Pasal 41 Undang-Undang 37 Tahun 2004 yakni dapat meminta untuk

\footnotetext{
${ }^{10}$ Imran Nating, Peranan dan Tanggung Jawab Kurator Dalam Pengurusan dan Pemberesan Harta Pailit (Rajawali Pers 2002).[39].

11 Zaeni Asyhadie, Hukum Bisnis Prinsip dalam Pelaksanaannya Di Indonesia (Raja Grafindo Persada 2014).[353-354].

12 Richard Burton Simaputang, Aspek Hukum Dalam Bisnis (Rineka Cipta 2003).[162].
} 
dibatalkannya terkait tindakan debitor yang justru perbuatan tersebut ternyata dapat merugikan kepentingan dari kreditornya ke Pengadilan. Pembatalan ini dapat dilakukan bila dapat dibuktikan bahwa ketika perbuatan hukum dilakukan oleh debitor dengan pihak siapa perbuatan hukum tersebut dilakukan seyogyanya mengetahui bahwa perbuatan hukum tersebut mengakibatkan kerugian bagi kreditor, kecuali perbuatan hukum berdasarkan perjanjian atau undang-undang, misalnya seperti membayar pajak. Ketika sebagai perusahaan yang mengalami pailit, maka menurut pasal 69 ayat (1) Undang-Undang Kepailitan menjelaskan bahwa kuratorlah yang memiliki tugas yaitu mengurusi serta melakukan pemberesan atas harta milik Debitor. Hal tersebut dilakukan ketika pengadilan mengucapkan putusan pailit pada debitor.

Bentuk dari akibat hukum pailitnya sebuah perusahaan sebagai perusahaan yang mengalami pailit, maka pekerja/buruh ketika bekerja untuk perusahaan yang pailit, memiliki hak untuk mengundurkan diri dari hubungan kerja, dan begitupula dengan kurator juga bisa memutus hubungan kerja dari perusahaan yang telah dinyatakan pailit, dengan adanya waktu pemberitahuan kepada pekerja setidaknya 45 (empat puluh lima) hari sebelumnya. Hal ini menurut ketentuan Pasal 39 ayat (1) UU Kepailitan dan Penundaan Kewajiban Pembayaran Utang.

Perusahaan Penyedia Jasa Pekerja sebagai perusahaan outsourcing, menurut ketentuan dalam pasal 65 ayat (3) Undang-Undang Ketenagakerjaan merupakan perusahaan yang berbentuk badan hukum, maka sebagai badan hukum bentuk yang paling tepat adalah berbentuk perseroan terbatas. Terhadap organ-organ perseroan terbatas atas debitor yang pailit, yakni direktur dan komisaris dari suatu perseroan terbatas yang dinyatakan pailit tidak diperbolehkan menjadi direksi dan komisaris dari perusahaan lainnya. Walaupun sebenarnya ketentuan ini menjadi kurang tepat dikarenakan mengingat bahwa kepailitan sebenarnya hanya berakibat hukum pada harta kekayaan milik debitor saja dan tidak berakibat pada hak-hak subjektif lainnya. Pada dasarnya kepailitan merupakan sitaan umum terhadap harta kekayaan 
milik debitor dan tidak mencakup sampai status pribadinya. Yang dimaksud dengan harta kekayaan, menurut Fred B.G.Tumbuan, yaitu semua barang dan hak atas benda yang dapat diuangkan. ${ }^{13}$

Eksistensi yuridis dari Perusahaan Penyedia Jasa sebagai perseroan terbatas yang telah dipailitkan dimungkinkan masih tetap ada eksistensi badan hukumnya. Alasan terhadap hal ini yaitu ada beberapa hal. Pertama, kepailitan terhadap perseroan terbatas tidak mesti selalu berakhir dengan likuidasi dan pembubaran badan hukum perseroan. Sebab jika seluruh harta kekayaan perseroan masih mencukupi untuk seluruh tagihan-tagihan kreditor, maka langkah selanjutnya adalah pengakhiran kepailitan tersebut dengan melakukan rehabilitasi terhadap perseroan terbatas agar suapaya dapat kembali seperti keadaan semula perseroan sebelum adanya kepailitan.

Alasan selanjutnya yaitu dapat dikatakan masih tetap eksistensi dari badan usaha perseroan yang telah dipailitkan, maka masih dimungkinkan untuk going concern atau melanjutkan usaha dari usaha dari usaha perseroan ini. Hanya saja jika perusahaan penyedia jasa mengalami likuidasi, maka perusahaan tidak boleh menjalankan bisnis baru namun hanya dapat menyelesaikan tugas-tugasnya dalam rangka untuk proses pemberesan dan likuidasi tersebut dan juga tidak dapat melakukan kegiatan di luar tugas tersebut. Hal ini termuat dalam ketentuan pasal 142 ayat (2) UU Perseroan Terbatas yang menyatakan bahwa dalam hal terjadi pembubaran perseroan.

Mengenai peran direksi ketika perseroan terbatas dinyatakan pailit, menurut Fred B.G. Tumbuan mengatakan bahwa memperhatikan tugas antara direksi perseroan yang pailit dan kurator hendaknya perlu diperhatikan bahwa direksi juga masih tetap mempunyai tugas mengusahakan tercapainya maksud dan tujuan perseroan pailit. Dengan demikian direksi juga harus mengupayakan agar tercapainya perdamaian dengan para kreditornya yang setelah dihomologasi

${ }^{13}$ Fred B.G. Tumbuan, Mencermati Makna Debitor, Kreditor dan Utang Berkaitan dengan Kepailitan, Dalam Emmy Yuhassarie (ed), Undang-Undang Kepailitan dan Perkembangannya (Pusat Pengkajian Hukum 2005).[127]. 
akan mengakhiri kepailitan perseroan agar perseroan bisa berlanjut sebagai "on going concern". Dalam upaya mengajukan rencana perdamaian, direksilah yang berhak mewakili perseroan dalam kondisi pailit. ${ }^{14}$

\section{Kesimpulan}

Dengan adanya klausula prinsip tindakan perlindungan bagi pekerja/buruh (TUPE) ini maka tidak menghapus kewajiban untuk membayarkan hak kepada pekerja/buruh karena kewajiban itu nantinya akan beralih kepada PPJP yang baru sehingga PPJP yang baru harus memberikan hak kepada pekerja/buruh dari perusahaan yang mengalami pailit.

Perlindungan hukum bagi pekerja/buruh yaitu kedudukan pekerja/buruh ketika perusahaan penyedia jasa mengalami pailit yakni sebagai kreditor preferen. Bahkan dalam putusan Mahkamah Konstitusi Nomor 67/PUU-IX/2013 dimana disimpulkan bahwa pembayaran upah buruh yang terhutang didahulukan atas semua jenis kreditor termasuk atas tagihan kreditor separatis. Hak-hak yang sepatutnya diterima oleh pekerja/buruh menurut ketentuan Pasal 165 UU Ketenagakerjaan bahwa pengusaha dapat melakukan pemutusan hubungan kerja karena perusahaan pailit,dimana pekerja berhak atas uang pesangon sebesar 1 (satu) kali ketentuan Pasal 156 ayat (2), uang penghargaan masa kerja sebesar 1 (satu) kali ketentuan Pasal 156 ayat (3), dan uang penggantian hak sesua ketentuan Pasal 156 ayat (4) Undang-Undang Ketenagakerjaan. Ketentuan ini diberikan kepada pekerja/buruh outsourcing ketika pekerja dengan perusahaan melakukan perjanjian kerja berupa Perjanjian Kerja Waktu Tidak Terntentu (PKWTT). Sedangkan untuk pekerja yang melakukan perjanjian kerja dengan perusahaan berupa Perjanjian Kerja Waktu Tertentu (PKWT), maka berlaku prinsip pengalihan tindakan perlindungan (TUPE), sehingga pekerja tidak sampai dilakukan pemutusan hubungan kerja kepada pekerja outsourcing. Tetapi

${ }^{14}$ Fred B.G. Tumbuan, Tujuan dan Wewenang Kurator Mengurus atau Membereskan Harta Pailit", Dalam Emmy Yuhassarie (ed), Revitalisasi Tugas dan Wewenang Kurator/Pengurus, Hakim Pengawas dan Hakim Niaga dalam Rangka Kepailitan (Pusat Pengkajian Hukum (PPH) 2004).[ 99]. 
pekerja outsourcing nantinya akan dialihkan kepada PPJP yang baru dengan tetap bekerja melanjutkan kontrak kerjanya, dengan tidak mengubah ketentuan isi dalam perjanjian kerja, tanpa persetujuan pihak-pihak yang berkepentingan, terkecuali jika sejatinya dapat meningkat keuntungan bagi pekerja/buruh karena bertambahnya masa kerja dan pengalamannya.

\section{Daftar Bacaan}

\section{Buku}

Adrian Sutedi, Hukum Perburuhan (Sinar Grafika 2009).

Agus Yudha Hernoko, Hukum Perjanjian Asas Proporsionalitas Dalam Kontrak Komersial (Kencana Prenada Media Group 2010).

Aloyosius Uwiyono, [et.,al.], Asas-asas Hukum Perburuhan (Raja Grafindo Persada 2014).

Fred B.G. Tumbuan, Mencermati Makna Debitor, Kreditor dan Utang Berkaitan dengan Kepailitan, Dalam Emmy Yuhassarie (ed), Undang-Undang Kepailitan dan Perkembangannya (Pusat Pengkajian Hukum 2005).

Fred B.G. Tumbuan, Tujuan dan Wewenang Kurator Mengurus atau Membereskan Harta Pailit", Dalam Emmy Yuhassarie (ed), Revitalisasi Tugas dan Wewenang Kurator/Pengurus, Hakim Pengawas dan Hakim Niaga dalam Rangka Kepailitan (Pusat Pengkajian Hukum (PPH) 2004).

Imran Nating, Peranan dan Tanggung Jawab Kurator Dalam Pengurusan dan Pemberesan Harta Pailit (Rajawali Pers 2002).

Lalu Husni, Pengantar Hukum Ketenagakerjaan Indonesia (Rajawali Press 2012).

Lanny Ramli, Hukum Ketenagakerjaan (Airlangga University Press 2008).

Marwati Riza, Perlindungan Pekerja Migran Indonesia di Luar Negeri (AS Publishing 2009).

Richard Burton Simaputang, Aspek Hukum Dalam Bisnis (Rineka Cipta 2003).

Zaeni Asyhadie, Hukum Bisnis Prinsip dala Pelaksanaannya Di Indonesia (Raja Grafindo Persada 2014). 


\section{Jurnal}

Andre Azka Hanifan, 'Perlindungan Hukum Pekerja Alih Daya Di Perusahaan Penyedia Jasa Pekerja Pailit’ (2014) XIX Perspektif.

Christopher Ganadhi, 'Tanggung Jawab PPJP Sebagai Penerima Pekerja Outsourcing Dari PPJP Sebelumnya Apabila Terjadi PHK' (2018) 1 Yuridika.

How to cite: Wira Maulana Aulia Akbar, 'Implementasi Klausul Transfer of Undertaking (Protection of Employment) Bagi Outsourcing Employee Perusahaan yang Jatuh Pailit’ (2021) Vol. 4 No. 1 Notaire. 
156 | Wira Maulana: Implementasi Klausul Transfer...

--Halaman ini sengaja dikosongkan-- 